\title{
The Argument of Geoffrey Hill's Odi Barbare
}

\author{
Stefan Hawlin
}

The fifty-two complex lyrics that make up Geoffrey Hill's 2012 volume

Odi Barbare $^{1}$ are rooted in the English poetic tradition via a wide range of allusions and also via the use of a stanza form gleaned from a poem in the Old Arcadia. 'If myne eyes can speake to doo hearty errand', 2 the poem in question, has been drawn to Hill's attention by Christopher Middleton's excellent praise of it in his 'Conversations with Marius Kociejowski'. ${ }^{3}$ So, the Sidney poem becomes a template upon which to fashion these extraordinary, beautiful, super-contorted lyrics. Partly in acknowledgement of this, the fifth stanza of the Sidney is excerpted as one of Odi Barbare's epigraphs:

Are then humane mindes priviledg'd so meanly, As that hatefull death can abridge them of powre, With the voyce of truth to recorde to all worldes, That we be her spoyles?

$$
\text { (p. vii) }
$$

\footnotetext{
${ }^{1}$ All quotation from Odi Barbare is from the first edition (Clutag Press, Thame, 2012), by kind permission of Clutag Press.

${ }_{2}^{2}$ It occurs in 'The First Eclogues' section: Philip Sidney, The Countess of Pembroke's Arcadia (The Old Arcadia) (Oxford 1973), p. 82.

3 Christopher Middleton, Palavers \& A Nocturnal Journal (Exeter 2004), pp.95-97.
} 
As Middleton says, 'It's grand, that. It's also obscure. You don't figure out what on earth it means to start with. It has a sort of luminous, blinding, dazzling splendour about it'.4 The question is stark, however, when we get it. Undoubtedly Hill wants to answer 'no', but a lot of hares have been set running. What words really do count in the valley of the shadow of death? In the Hopkins-like beginning of the last ode, LII, we have this echo of 'Carrion Comfort': 'Not faced death, not been there, not done with dying' (1. 1). In his late seventies, the poet writes, spiritually if not physically, in extremis. What in his ethos and his technic (to use two of his own terms) - in what he says, and in his manner of saying it - can really brave the ending of life?

Odi Barbare's second epigraph is supplied by Aeneid II, 509-11:

arma diu senior desueta trementibus aeuo circumdat nequiquam umeris et inutile ferrum cingitur ac densos fertur moriturus in hostis

In Surrey's translation:

Th'old man in vaine did on his sholders then, Trembling for age, his curace long disused, His bootlesse swerd he girded him about, And ran amid his foes, redy to dye. 5

Troy is nearly lost; a civilization is coming to an end. Old king Priam, trembling with age and rage, struggles into his armour for the last time

\footnotetext{
4 Ibid., p. 97.

5 Henry Howard, The Poems of Henry Howard, Earl of Surrey, ed. Frederick Morgan Padelford, rev. ed. (Seattle 1928), p. 131.
} 
desperate to defend it. In something of this fashion Hill sees himself as setting out once more, in what he elsewhere calls his 'scant-extended age', ${ }^{6}$ to do battle with the signs of the times.

\section{Evil}

Hill believes in original sin, our nearly aboriginal self-alienation, not as a theological deduction (though it can be that) but as something that can be read off from the perversities of the individual heart, and collectively from humankind's self-hating addiction to war, injustice, and cruelty. Evil is a fact of species' life, and is a ground-note in this volume, as in much of Hill's work. There are various small disasters and betrayals, but it is big events that form the backdrop: in XXXV the Battle of Passchendaele, with nearly 750,000 soldiers killed; in XXXVI the destruction of the majority of the shtetls in the wake of the German advance into Russia in 1941; in II the brutal ending of the fighting of the Second World War in Italy; in $\mathrm{V}$ the contemporary aggravations and atrocities surrounding the state of Israel. The central meditation on evil concerns the Holocaust, not exactly a new topic for Hill but one which he again treats here with searching originality.

For a start, this poem, Ode XXVI, is not about the Warsaw ghetto or Auschwitz-Birkenau, but is focused instead on the fate of the Jews in the

\footnotetext{
${ }^{6}$ Hill, Clavics (London 2011), no. 6: p. 16.
} 
ghetto in Łodz (pronounced Wodj), a story with which fewer readers are probably familiar. The Jewish population in Łodz, first cordoned off into the north-east section of the city, was liquidated through the course of the war by starvation, disease, and massive relocations to the deathcamps.7 A once thriving Jewish population of 250,000 was reduced to almost nothing. The Łodz ghetto also acted as a holding-pen for Jews brought from other parts of Europe, funnelled through to extermination. The ode begins almost casually: no 'see-here' or hyperbole is required: 'Łodz: I've been there, done that. The vanished children' (l. 1), i.e. the poet has written about the Holocaust before, and one of the most poignant early aspects of life in the ghetto was that children under eightyears-old were some of the first taken off and killed: 'The vanished children' is nonchalant and chilling. Then there is the switch into the second line: 'Klezmer makes glad music at Larazus' gate'. Here we have both 'Hark, hark, the lark at heaven gate sings, / And Phoebus gins arise' (Cymbeline, 2. 3. 19-20) and the lark that 'from sullen earth, sings hymns at heaven's gate' (Sonnet 29), and an allusion that seems to combine Lazarus the poor man and Lazarus of Bethany. Klezmer (the wonderful Jewish folk music, which non-Jews will most readily associate with weddings) is testimony that the Holocaust has in some sense been survived by the Jewish people: 'If as straggling voices the dead return

\footnotetext{
7 Chronicle of the Lodz Ghetto, 1941-1944, ed. Lucjan Dobroszychi, trans. Richard Lourie (New Haven, Conn. 1984), is one of the most extraordinary Holocaust documents, a factual, low-key, blow-by-blow account of life in the ghetto over the period, written by the victims themselves.
} 
now / They have our number' (ll. 3-4) - the connection between the massacred generations and the present generations is always there; the Holocaust is (almost) universally acknowledged.

So far, so good. But the next lines disconcert us, as the poet whisks us off to his own 1930s-40s' childhood in Worcestershire:

Breathing hard we wrestled asbestos brake-pads;

Luminously radioactive watches

Fizzled green plaque riding elastic wrist-bands;

Glue smelt of peardrops.

Someone those taut days was predicting biros.

Surreal fantasy here is actually literal fact. Children's bikes in the 1930 s did employ asbestos in their brake-pads. Watch dials, which glowed green in the dark, were produced both under the trademark 'Undark' by the Radium Dial Company, and also by the US Radium Corporation, using a paint mixture that contained radioactive radium. The biro (in the US 'the ball-point pen’) was patented by László Bíró in 1938 and came into wide use in Britain after the war. The effect of all this is very similar to the effect of 'Zyklon' (6) in Hill's iconic 'September Song'. ${ }^{8}$ Not only do we have in five bare lines all the high-jinks of childhood - the bike races, the showing off of one's new watch to friends - but we have the terrible reminder that this was a world that thought of itself, in part at least, as

\footnotetext{
8 Hill, Collected Poems (London 1985), p. 67.
} 
modern and progressive. In those 'taut days' someone was 'predicting biros' (l. 9) - a matter of interest to the schoolboy grappling with his blotty fountain pen - but few had any intuition of the scale of the Holocaust.

By placing his own childhood side by side with the 'vanished children' of Łodz, Hill encapsulates in a small space an important part of his vision of evil: how, at its worst, it seems to exceed explanation. For him there may be many identifiable causal reasons for the Holocaust - historical, political, sociological, and so forth - yet in the way in which what actually happened violates the liberal imagination's view of what humanity actually is, we have a compelling if paradoxical argument for religious faith, along the lines of the kind of theodicy that might be derived from Job 38. Implicit in Hill's view is the sense that the monstrous birth of the Holocaust invalidates at a stroke all progressivist or Whiggish views of history (though, no doubt, they will always seek their own revival and rehabilitation); for him, any sense of a respectable self-image for humankind, outside of a theological frame, is an impossibility.

Back in his childhood, Hill notes wryly that one of his friends was a Jew who 'blubbered' easily and who was 'bright, a bully' (l. 10). Clearly he suffered under this boy's ministrations. Some people saw aspects of the Holocaust coming: 'Many then had foresight but I was not one' (1. 14). And then, in just two lines, he captures authentically his own childish view of the pre-war condition of the Jews: 'Vital spinners counting, 
there's no subtraction / Ever can oust them' (ll. 15-16). This evokes Jewish energy, hard work, productivity (the usual cultural clichés), and the sense that the Jews were a solid matter-of-fact reality in European life. The end of the poem, as a reminder of suffering, describes with poignancy the loveliness of the clarinet in Klezmer music, but then the world presses on at its own relentless pace: 'Hurl of things fastbound the last-known survivors' / Wailed diminution’ (11. 23-24).

\section{Cultural memory}

As a Christian poet, history for Hill is necessarily a shape encompassing the Fall, the Incarnation, and the end-time.9 Such a short-hand formulation no doubt violates via simplification the mystery it describes, and Hill himself is more tactful and introspective in the ways in which he sets out to address the issue of cultural memory and the related issue of providential history. In fact, his own comments sometimes appear to offer less than his actual embodied thought in his poetry. In 1980, for example, in a New Statesman interview, he said this: 'I think that it is a tragedy for a nation or people to lose the sense of history, not because I think that the people is thereby losing some mystical private possession, but because I think that it is losing some vital dimension of

\footnotetext{
9 See, for example, Speech! Speech! (London 2000), no. 15: p. 8.
} 
intelligence'.10 In a recent essay, Rowan Williams puts a different slant on this thought: 'The point is not that the past is good, and the present bad by comparison; it is that a present which has no sense either of gift or of loss in relation to the past is in serious ways a barbarized and impoverished environment.'11 Just as our individual childhoods are profoundly shaped by the family and social environments we inherit, so the larger history of a nation is a warp and weft emerging from the past from which we cannot egoistically split ourselves off.

In this respect his religious humanism is very similar to that of $\mathrm{T}$. S. Eliot, as expressed for example in the choruses of his pageant play The Rock. Here are some of Eliot's grandest declarations:

... here upon earth you have the reward of the good and ill that was done by those who have gone before you.

And all that is ill you may repair if you walk together in humble repentance, expiating the sins of your fathers;

And all that was good you must fight to keep with hearts as devoted as those of your fathers who fought to gain it.

(from Chorus II) ${ }^{12}$

Hill's implicit argument is that the contemporary mindset lacks this reverent sensitivity to the past and to how we fit into an ongoing story. As he puts it bluntly in The Triumph of Love, England is 'a nation / with so many memorials but no memory'. ${ }^{13}$ History saturates Odi Barbare as

\footnotetext{
10 'Under Judgment', interview with Blake Morrison, New Statesman (8 Feb. 1980), p. 213.

${ }^{11}$ Rowan Williams, 'The Standing of Poetry: Geoffrey Hill's Quartet', in Geoffrey Hill: Essays on His Later Work, ed. John Lyon and Peter McDonald (Oxford 2012), p. 64.

12 T. S. Eliot, Collected Poems 1909-1962 (London 1963), pp. 167-8.

13 Hill, The Triumph of Love (London 1998), sec. LXXVI: p. 40.
} 
much as Hill's earlier volumes, but aspects of this theme of cultural memory now emerge with new clarity.

Ode $\mathrm{XXXV}$ is again a poem that can be drawn into this context: 'Conscript fathers, hell-bent from wars returning, / Ninety years gone here to redress the summons' (ll. 1-2). The 18-year-olds conscripted into the army by the Military Service Act of 1916, who survived the war, lived on into the 1980s and 1990s (the last English combat veteran of World War I died in 2009). After the hell of the Passchendaele campaign, lives had to continue, be pieced together, remade, with few notions of psychological stress or PTSD. The First World War, in short, lasted a lot longer than 1918, and 'history' is not the simplified pattern we so often suppose: it is close, biological, intimate; to apprehend it meaningfully demands that we live within a sense of the community of the generations.

Ode VI is the place where Hill really addresses this issue head on, though initially no doubt it may look like only a sepia-coloured recreation of the Anglo-Zulu war (1879) and the Battles of Isandlwana and Rorke's Drift. Will the old charges against Hill of historical nostalgia be revived? Perhaps the charge seems even more plausible at the point where the reader realizes that Hill is also referring to the historical re-enactments of these battles in the Hollywood films Zulu Dawn (1979) and Zulu (1964). Who can forget Michael Caine, in Zulu, in the role that made his career, as the upper-class Lieutenant Gonville Bromhead? The films purport to be 'the truth', but their sensationalism, anachronism, and 
melodrama obviously do create 'soldiery's grand comedy' (1. 26), only, in reality - as the pun here makes clear - 'soldiery's grand comedy plays to curtains' (emphasis added), i.e. entertains us (receives curtain calls) and leads to sacrifice and death (as in 'it's curtains for them'). The invasion of Zululand in January 1879 by a British army under the command of Lieutenant-General Lord Chelmsford, 'Errant Chelmsford' (1. 13), led to one of the most mismanaged of imperial wars. Within his theme of the importance of cultural memory, Hill sets it down defiantly as part of the reality that was imperial Britain.

For me, it is the moral poise of this ode that is so telling, since it neither endorses the view of Empire that sees it as all bad and shameful, nor endorses some simplistic heroic view, nor the recent kind of history (for example, Niall Ferguson's neoimperialist view) that wants to see the Empire as, on balance, a good for the wider world. Here the summative scope of such judgements, their level of generalization, becomes suspect in the face of the intimacy of bravery and suffering. As depicted here, the Anglo-Zulu war is a mixture of farce and heroism, sin and grace. We may note, for example, the balancing act of the third stanza. On the one hand, the horror of the assegais (the Zulu spear, pronounced 'ass-uh-guys'), on the other hand the deadly effect of the British army's breech-loading 'one-shot' Martini-Henry rifles. This stanza has a flagrant air, even an air of pastiche, but it is pressing on us the horrible texture of events:

Assegais whish-washed in the fleshy Empire Jelk you inside out like a dumdum bullet; 
Death by numbers, one-short Martini-Henry

Redhot on target.

(ll. 8-12)

The dignity given to both the Zulus and the British soldiers in this poem forces us to step outside many of our current clichés about Empire and its aftermath.

\section{Prophecy}

For many years now Hill has been a social critic willing to take on the prophetic role, and this is an important element in considering Odi Barbare as a whole. What could be called prophetic, indeed angry, poems have to be read within the larger, very personal context set up elsewhere in the collection. Hill has said of Yeats and Eliot that 'each in his own way, throughout the 1920 s and 1930 s, . . . fought for the intelligence of poetry within the civic domain,'14 and he undoubtedly sees himself as continuing this fight in the troubled circumstances of today. The critiques he offers are humble ones, rooted in his profound love for a country that he believes is going seriously wrong, and rooted too in a strong self-irony concerning his own role as castigating prophet.

${ }_{14}$ Hill, Collected Critical Writings, ed. Kenneth Haynes (Oxford 2008), p. 579. 
Nonetheless, what he has publically called 'the bankers' scam' has clearly affected him deeply. 15

There are two particular sources for his moral thinking here: the lectures comprising John Ruskin's Unto this Last (1860), and William Morris's 'Art under Plutocracy', the most important of the Lectures on Socialism (1883). 'Ad Valorem', the last lecture of Unto this Last, in its nuanced discussion of what 'wealth' actually and really is - as opposed to the alienated or distorted views of wealth that are in vogue - and its wonderful description of what really constitutes the wealth or well-being of society, reads like a tract for our times as well as the times for which it was written. ${ }^{16}$ Similarly Morris's critique of a society intent on prioritizing notions of 'competition' over those of 'co-operation', and of reinforcing 'that terrible organization of selfishness' which is the class system, is another powerful text for today to which Hill is drawing attention. ${ }^{17}$ In Ode XXXIX he takes up Ruskin's word 'illth' (the distorted misunderstanding and misuse of 'wealth' so-called, breeding social injustice), ${ }^{18}$ and a variation of Morris's phrase 'anarchical Plutocracy', ${ }^{19}$

\footnotetext{
${ }^{15}$ Hill, 'How ill white hairs becomes a fool and jester', Inaugural lecture, Professor of Poetry, University of Oxford, 30 November 2010. Podcast at http://www.english.ox.ac.uk/news-events/regular-events/professor-poetry.

${ }^{16}$ John Ruskin, Unto this Last, in The Works of John Ruskin: Library Edition, ed. E. T. Cook and Alexander Wedderburn, 39 vols. ( London and New York 1903-1912): vol. XVII.

${ }_{17}$ William Morris, 'Art under Plutocracy', in The Collected Works of William Morris, ed. May Morris, 24 vols. (London 1910-15): vol. XXIII, pp. 164-91 (191). In his lectures as Professor of Poetry at Oxford University in 2011, as yet unpublished, Hill made much of 'Art under Plutocracy'.

${ }^{18}$ For the coinage and discussion of the term 'illth', see Ruskin, p. 89.

19 Morris, p. 191.
} 
i.e. 'Plutocratic anarchy' (l. 13), to begin to expose the mindset that lies at the root of our present troubles.

No short summary is going to do justice to either Ruskin or Morris here, and I take it that what Hill is partly doing in this ode - and in the related poem, Ode XIII - is simply pointing to these great social thinkers and demanding that we reread them urgently. In effect what he is saying is that we are living at a moment of historical recurrence, in which these thinkers become newly pertinent. The following, for example, from Ruskin's Unto this Last, might surely give us pause:

That country is the richest which nourishes the greatest number of noble and happy human beings; that man is richest who, having perfected the functions of his own life to the utmost, has also the widest helpful influence, both personal, and by means of his possessions, over the lives of others. ${ }^{20}$

Ode XXXIX joins up these ideas about true wealth and 'illth' with the speeches in Timon of Athens where Timon, after his fall, attacks the corruptions and distortions brought about by the wrong valuing of money. 'Throat-cutting' (1. 3), as alluded to here, is an idea that occurs several times in the play, as for example, when Timon tells bankrupts to 'hold fast': 'Rather than render back, out with your knives, / And cut your trusters' throats' (4. 1. 9-10). All Timon is doing in this and related speeches is slightly exaggerating the conditions of selfishness, greed, and unkindness which he now sees as pervasive. Hill is awed by the rhetorical

${ }^{20}$ Ruskin, p. 105. 
power of the great speeches in Act 4, and the quality of their attack on the wickedness of humankind in relation to wealth: 'Massive those turbines of a salt invective' (1. 10). He would like, in the same way, to 'bear witness', if, as an old man, he could survive the sheer 'rift' of his own anger (1l. 10-11).

Art

It is when we turn to the question of the arts, and their potential meanings, that we may feel we are getting near to the centre of the argument in Odi Barbare, for the volume is saturated with allusions to artists, novelists, and poets, sometimes via extended reference and sometimes via the briefest or most implicit mention. From one point of view, it is very touching to see a long-practiced and fine poet, in his late seventies at the time of writing, thinking these things through again, but there is nothing sentimental here. Hill is not offering some formula for 'the function or meaning of poetic art in times of trouble'. He offers glimpses and suggestions, what Heaney would call 'echo soundings'. Different poems maintain different moods, and to that extent different implications. 
One affinity that can be felt here is with Hannah Arendt (1906-1975), a thinker who has meant much to Hill, ${ }^{21}$ in particular her Between Past and Future (1961) and her Lectures on Kant's Political Philosophy (1982). Long before our present partly postmodern cultural condition, Arendt was already picking up the drift of the times and thinking hard about the differences between 'culture and art' (and their 'permanence' or 'timelessness') and 'mass entertainment'. The danger under present conditions is that 'culture ... is eventually absorbed into the consumer society's need for entertainment, by virtue of an all-encompassing functionalization'. ${ }^{22}$ This phrasing is from Ronald Beiner's summary of Arendt's position in her essay 'The Crisis of Culture: Its social and Political Significance'. Implicitly, this is a position that Hill agrees with, and he certainly does not see it as in any way 'elitist'. Here is Arendt in her own words:

Culture relates to objects and is a phenomenon of the world; entertainment relates to people and is a phenomenon of life. An object is cultural to the extent that it can endure; its durability is the very opposite of functionality, which is the quality which makes it disappear again from the phenomenal world by being used and used up.... A consumers' society cannot possibly know how to take care of a world and the things which belong

\footnotetext{
${ }^{21}$ A particular telling late mention of Arendt occurs in 'A Postscript on Modernist Poetics': Collected Critical Writings, p. 573.

${ }^{22}$ Ronald Beiner, 'Introspective Essay', postscript to Hannah Arendt, Lectures on Kant's Political Philosophy, ed. Ronald Beiner (Brighton 1982), pp. 102-03.
} 
exclusively to the space of worldly appearances, because its central attitude toward all objects, the attitude of consumption, spells ruin to everything it touches. ${ }^{23}$

Ode XVII can be read in the light of this remark. The questions it is posing are these: What survives against the flow of time? Why does it do so? But there is also a very personal note here, as the ageing poet faces the vulnerabilities of his own physical and mental states: 'Face of such woes grins elegiac triumph' (1. 5) - it is almost as though he (with Hamlet) were staring at Yorick's skull. There are nine months in the womb to get ready for life; perhaps we should have a designated nine months at the end of life to ready ourselves for the 'labour / Strange' of death (ll. 7-8). But then the tone rallies. Even as the poet falls and stumbles - even amidst the brokenness of age - there is the hope that the integrity resulting from weakness might lead to the artistic holy grail: 'substance, / Splendida verba' (ll. 11-12). And when he thinks of an instance of such poetry, he thinks again of the passage in the Aeneid, Book II, from which he takes his epigraph. Hill is clearly deeply moved by this image of Priam 'gorgeously shaken' (1. 21). But then comes the twist in the tail: 'That the severed image [the body cut through with Pyrrhus's sword] defies extinction / Gives me the shivers' (ll. 27-28, emphasis added). The 'splendida verba' is something that lasts. And this points us back to the fourth stanza:

${ }^{23}$ Arendt, Between Past and Present: Six Exercises in Political Thought (New York 1961), pp. 208, 211. 
That we do gamble and that who accepts may

Call us on it: words as their own tribunal,

Stelae shown hallowed by the goddess Justice

Though but a fiction.

(1l. 13-16)

Serious writing is a risk, and the goddess Justice will sort all writing into the wheat and the chaff. Even so, 'though but a fiction', poetry can survive to vivify and console us.

Ode XXXVII strikes a different, more troubled note, and may appeal to more readers on just that account. It concerns the execution of Thomas Cromwell on 28 July 1540, on Tower Green, and the devastated grief of his friend Thomas Wyatt, poet and diplomat, who was there at the end. ${ }^{24}$ No doubt lines 2-6 will appear obscure to some, but in fact they make simple points: 'Wyatt slipped his luck to a falcon's shadow' (l. 2) alludes to Wyatt's 'Lucks, my fair falcon, and you fellows all', and so to the period of imprisonment that Wyatt suffered after Cromwell's execution. Also, perhaps, via the image of the falcon (Anne Boleyn's badge or emblem), it may allude to Wyatt's earlier imprisonment in 1536 when, because of his supposed intimacy with Anne, he was embroiled in the case leading to her execution. Now Hill hears 'witticisms' knell' (l. 3) in the poem that Wyatt is traditionally supposed to have written in response to Cromwell's execution, 'The pillar perished is whereto I leant'. That poem is the death, as it were, of all that Renaissance sense of wit and elegance that is such an important element of style and meaning in

${ }^{24}$ For a description of this, see Susan Brigden, Thomas Wyatt: The Heart's Forest (London 2012), pp. 524-25. 
Wyatt's verse. How can art stand up in the face of the brutality and intransigence of life? In this test-case, What is the point of it in the face of the tyranny of Henry VIII? The poet is in dialogue with his attentive reader: 'Endless invention are you saying why have / Endless invention?' (1l. 7-8).

This is another stark question, since any artistic career must be premised to some extent on 'endless invention'. We are being pointed to another subtext, in this case the opening chorus of T. S. Eliot's The Rock:

Endless invention, endless experiment, Brings knowledge of motion, but not of stillness;

Knowledge of speech, but not of silence;

Knowledge of words, and ignorance of the Word.

All our knowledge brings us nearer to our ignorance,

All our ignorance brings us nearer to death,

But nearness to death no nearer to GoD.

Where is the Life we have lost in living?

Where is the wisdom we have lost in knowledge?

Where is the knowledge we have lost in information?

(Chorus 1, ll. 7-16) 25

Certainly Eliot himself went beyond this position in his later career, in order to continue writing, but this is surely a continually available mood within Christian humanism, a blunt reminder of the 'vanity of vanities'. Hill brings two things into play in answering this mood's challenge: partly an acknowledgement of the 'vanity of vanities', and then a turning to a strange kind of joy in art itself. At least, this is how I read the mood of the poem's ending, where, having briefly surveyed the later careers of Yeats, Pound, and Stevens, and how time and distance adjusts our view

25 Eliot, p. 161. 
of those careers, he makes sense of his own ongoing career through 'both toc- /Cata and spieltrieb' (1l. 23-24). The light, improvisational quality of a toccata stands here for the sheer fun and games of art, the playfulness, the joy of it. This is picked up in the reference to 'spieltrieb' ('the play drive'), as analysed by Friedrich Schiller in On the Aesthetic Education of Man. ${ }^{26}$ To Schiller, and for Hill also, the 'play drive' creates the breakthrough space between purely sensuous and purely rational apprehension, so that the aesthetic is one of the cornerstones of human civility and dignity. If that puts a lot in a short space, Hill is even briefer. His notations are pointers and hints, not fully fledged solutions to huge dilemmas.

\section{Faith}

It seems predictable, I think, that much of the complex and involved nature of Hill's utterance in this volume will prove controversial. After all, Hill deliberately eschews what he has called 'the savage and canting populism' of our times, and has mocked some notions of 'accessibility' in art. ${ }^{27}$ There are no concessions in Odi Barbare to the indifferent, unenergised, or unformed reader. Various defences of his own 'difficulty'

\footnotetext{
${ }^{26}$ Friedrich Schiller, On the Aesthetic Education of Man, trans. Reginald Snell (Mineola, NY 2004), pp. 8, 74-7, 79-80, 112, 126, 135.

27 Hill, 'How ill white hairs'.
} 
have peppered his career, ${ }^{28}$ and one of his favourite critical quotations is this typically modernist statement from the American critic R. P. Blackmur: 'The art of poetry is amply distinguished from the manufacture of verse by the animating presence in the poetry of fresh idiom: language so twisted and poised in a form that it not only expresses the matter at hand but adds to the stock of available reality.'29 This clearly captures the spirit of Odi Barbare's ambition. All too evident in these odes is the 'twisting' of language; so too, however, is what they take from the structure of the metrical form, which continually acts to lift up the emotional affect. No doubt the 'twisting' and the difficulty that goes with it will be criticized by some. It is interesting, however, that the poems where 'twisting' and 'poising' really work well together are often those concerned with deep kinds of happiness, often with some kind of religious under-pinning.

Ode XXV, for example, is a response to Richard Lovelace's beautiful lyric 'Gratiana Dauncing and Singing' (1649), where Hill re-evokes the figure of a seventeenth-century woman dancing in masque mode, and sees in her 'noble' frame, and in the composed and balanced nature of her dance, an image of spiritual perfection. Ode XXVIII is an evocation of first, adolescence love: the poet freely concedes that, had this romance gone on to marriage, it would have proved folly, but wants to register the

${ }^{28}$ E.g. 'Geoffrey Hill [interview]: The Art of Poetry No. 80', The Paris Review 154 (Spring 2000).

${ }^{29}$ Quoted here from Hill, 'How ill white hairs'. It was originally the opening sentence of a book review by Blackmur that appeared in Poetry (May 1935), but was thrown into prominence by John Berryman's use of it in his poem 'Olympus', in Love and Fame (New York 1971). 
delight of 'that chanced day brief as the sun's arising' (1. 22) which was another glimpse of the higher life. Ode XXXII, one of the most obviously Hopkins-derived poems, gives us a magnificent springtime scene on Pendle Hill, Lancashire, narcissi and blackthorn bursting into bloom, 'telling what message if not resurrection' (1. 10). And Ode XLVI gives us 'disruptive' laughter at a funeral, perhaps the poet's own, this laughter being somehow affirming and life-giving amidst the necessary 'formalities' and the 'deeper sense crafting us mute' (l. 13).

The great poem in this context is Ode $\mathrm{XLV}$, which we might reasonably call Hill's version of 'The Windhover'. (Most readers, I think will be struck here by lines 5-6 as a wonderful echo of Hopkins's manner.) In the opening of the ode, the poet looks at a beautiful autumn landscape probably, from hints in the first stanza, somewhere in north Wales - and is profoundly engaged with the scene. His heart's 'well' (1. 7) - its most intensely living depths - finds itself echoed in the sheer loveliness of the landscape. Just at this point, he sees a buzzard flying overhead and his 'heart in hiding / Stirred for a bird, - the achieve of, the mastery of the thing'; in Hill's bold reworking of those famous lines:

Throps a buzzard, lazily photographs his Aerial scenics. Be a fool and say so: Adamantine age set to melt in flames of Absolute longing.

(ll. 21-24)

'Throps' is a joyous coinage, evoking the sound stroke of the buzzard's wings in flight, as it slowly takes in the panorama of the scene below it. 
This playful, Hopkins-like inventiveness with language is also there in the opening stanza:

Here at full noon only endormant cloudscapes, Active curtailed nerves of the earth-scarps braded, Flense of some late glacier's vanished keel yet

Cutting between them. (ll. 1-4)

Meaning here is surely no harder than in Hopkins. I assume something like this is meant: 'Here, at full noon, there are the sleepy, barely-moving late summer clouds, which seem to be like nerves reaching out a certain way from the smoothed but sharp-sided hills - we can still almost imagine the knife (the flense) of the glacier's bottom cutting the valley shape between them'. The 'cloudscapes' are the 'active curtailed nerves' of this landscape because they seem to be rising up, evaporating, out of it. 'Flense' is presumably a shortened form of 'flensing knife' (curiously, not covered properly in $O E D), 30$ the knife used to cut the blubber off whales, and hence generally a knife used for skinning animals. Within this landscape, in the second stanza, the gorse's vivid yellow is 'conclamant' (1. 5). This gorse 'rakes and reivers' [i.e. grabs and invades] barrens' (1. 6), i.e. the barren areas of the fells. ('Reivers' is still a term known in the north of England for cross-border raiders or cattle-stealers, though here it is employed as a verb. ${ }^{31}$ )

\footnotetext{
$3^{30}$ One instance is given en passant under the verb entry 'flench | flinch | flense'. ${ }^{31} \mathrm{OED}$ gives it only as a noun, under the spelling 'reaver'.
} 
The middle stanzas hinge on a witticism attributed to the film star Bette Davis (1908-1989): 'Old age is not for sissies'. We have here a slightly modified form of it: 'old age is / Not for the squeamish' (1l. 1112). The poet challenges the attitude behind the witticism because he is now of an age (eighty) to match Davis's, and with the usual health problems, but he refuses to take on the mantle of stoicism in the face of death. Life is a good, even if it ends. No Phaedo for him. 'I do not see us reabsorbed in nature' (1. 14): we are molecules reabsorbed in the earth, but not only that. He will rework, in a flirtatious or fresh way, Davis's witticism in order to challenge it. Man is in love and loves what perishes, but - so what? In old age comes an intensification of eros, and hence of delight in the natural world, and in the sense of that world's fundamental goodness. Art (in the shape of the Prelude to Debussy's Cello Sonata in D minor) comes in here to set up the final stanza: the kind of old age that the poet 'signed for' is that which he finds enacted emotionally in Debussy's music. Art is part of the way in which we are in love with the world, the good, God-given world. Even in 'adamantine age' the poet finds himself in love with nature and its loveliness:

This is what I signed for-musicien français

But in English-as when that time-eliding Brief rhapsodic lento begins Debussy's Cello Sonata.

Throps a buzzard, lazily photographs his Aerial scenics. Be a fool and say so: Adamantine age set to melt in flames of Absolute longing. 
(11. 17-24)

This, I take it, is the high-point of the argument in Odi Barbare. The poet has sung the psalms of despair; now he sings the psalms of joy. We might say simply that the collection takes us from the horrors of Łodz and Passchendaele to this extraordinary, elevated, elated moment. 
This is a pre-copy edited, author-produced version of an article accepted for publication in The Cambridge Quarterly following peer review. The version of Hawlin, Stefan (2013) 'Argument of Geoffrey Hill's Odi Barbare' is available online at:

https://doi.org/10.1093/camqtly/bft041

doi.org/10.1093/camqtly/bft041 